\title{
Isolation, Enumeration and Antibiotic Sensitivity Pattern of Bacteria from the Hands of Commuters in Akure Metropolis
}

\author{
Ologun Oluwabusayo Mary*
}

Department of Microbiology, Federal University of Technology, P.M.B. 704, Akure, Nigeria

*Corresponding author

\begin{tabular}{l} 
K e y w o r d s \\
$\begin{array}{l}\text { Fecal bacteria, Pathogenic } \\
\text { microorganisms, Proper } \\
\text { hygiene, Antibiotic } \\
\text { susceptibility, Hand- } \\
\text { contamination }\end{array}$ \\
Article Info \\
$\begin{array}{l}\text { Accepted: } \\
\text { 04 October } 2018 \\
\text { Available Online: } \\
\text { 10 November } 2018\end{array}$ \\
\hline
\end{tabular}

A B S T R A C T

This study was designed to isolate and determine the antibiotic sensitivity pattern of bacteria associated with the hands of commuters in Akure metropolis. The samples were collected using sterile swab sticks at different motor parks (Obaile, Oke-Ijebu, Benin, FUTA and Road block), then transported to Microbiology laboratory for further analyses. Isolation of microorganisms was carried by direct plating on the bacteriological media. The plates were incubated at $37^{\circ} \mathrm{C}$ for 24 hours. Enumeration of the bacterial isolates was done by direct count of the colonies formed on the plates. Pure bacterial isolates was obtained by repeated streaking on the fresh media. Different bacteria were isolated. Staphylococcus aureus recorded high frequency (90\%) while Escherichia coli recorded least frequency (12\%). All the Gram negative bacterial isolates were susceptible to some of the antibiotics with varied zone of inhibition. Shigella spp was susceptible to ciprofloxacin with zone of inhibition $5.0 \mathrm{~mm}$. Escherichia coli and Staphylococcus aureus were resistant to pefloxacin. High microbial loads recorded from the commuters indicated the level of contamination. Therefore, hand sanitization, proper hygiene and the use of antibiotics could help in the control and spread of antibiotic resistant bacteria from fecal origin.

\section{Introduction}

Human hands perform many functions on the human body. Due to involvement of humans in various activities, it is easily exposed to environmental contaminants such as dust, body fluids, surfaces, pollutants, wastes, spoilt materials and during personal hygiene (Ahmad et al., 2014).

Human hands have been implicated as the major transmitter of microorganisms among individual or from one person to another. It is often act as vectors in the spread of pathogenic microorganisms such as bacteria and viruses from person to person, either through direct contact or indirectly via surfaces (Oranusi et al., 2013). Lack of personal hygiene such as poor sanitary conditions can facilitate the transmission of some of these pathogenic bacteria found in the environment to human hands (Curtis and Carncross, 2003). Proper hand washing in public places as best traditional first line of defense can help in preventing the spread of disease and confer healthy living (Patel et al., 2010). Though lack 
of water source such as borehole in public places is one of the major challenges facing the populace (Lau et al., 2012). Improper hand washing without using soap after leaving the restroom contribute greatly to the spread of fecal microorganisms (Barker and Bloomfield, 2000). Human hand to hand contact serves as express means of fecal-oral transmission of various enteric microorganisms capable of causing illness (Prescott et al., 2005).

The skin covering the outermost parts of human hands acts as barrier for the invasion of pathogenic microorganisms and unwanted materials into the body system. Skin is one of the major sense organs covering various parts of the body. It acts as physical barrier, preventing infections of subcutaneous and systemic tissues through the production of sweat and sebaceous secretions containing fatty acids and lysozyme with antimicrobial properties (Ray et al., 2011). Human skin supports the growth of different commensal bacteria as resident candidate on the skin which protect the host from pathogens. Microorganisms are ubiquitous, they can be found on surfaces, air, water, foods, dust and human skin (Rote et al., 2010). Generally, human hands are the major source of microbial contamination mostly acquired by contact with objects or with the environment. Contamination of human hands can occurred as a result of various activities involving hand shaking, touching of contaminated surfaces and farming which principally play a key role in the spread of infectious diseases causing mortality if left untreated (Johnson et al., 2002). Human hands play a crucial role in most human movements and activities. Human hands serve as a reservoir for large number of culturable microorganisms, considerably capable of causing diseases (Dodrill et al., 2011). Environmental and local factors, host immunity, and microorganism adherence and virulence are intricately related to skin infection. Resident bacteria such as
Micrococcus, Corynebacterium, Staphylococcus, Enterobacteria, Salmonella, Shigella, Escherichia, Proteus, Citrobacter, Enterobacter, Klebsiella, Clostridium, Streptococcus and Pseudomonas are notoriously pathogenic microorganisms found to be transient on the human skin (WHO, 2009).

Environment plays a critical roles in the transmission of infectious diseases either directly through hand to hand contact, or indirectly, via food or other inanimate objects like fomites (AlGhamdi et al., 2011). Human beings serve as a major vehicle in the transmission of fecal bacteria from one place to another as a result of hand washing after toileting or direct contact with the fecal droplet. Human hands usually harbors microorganisms both as part of person's normal microbial flora as well as transient microbes acquired from the environment (Lindberg et al., 2004).

Fecal bacteria are naturally found in faeces of humans and animals. Contamination of hands is one of the important route by which humans are exposed to pathogenic organisms (Langford, 2009). They are usually transmitted by faeco-oral route, usually causes gastrointestinal infections with the symptoms including diarrhea, food poisoning caused by Staphylococcus aureus, enteric fever caused by Salmonella typhi, Shigellosis caused by Shigella dysenteriae (Boschi-Pinto et al., 2008).

Diarrhea is a serious global public health problem. The World Health Organization estimated that over 2.2 million deaths occurred due to diarrhea infections occur annually, especially among children less than five years of age (WHO, 2002).

Bacteria of fecal origin can be found on the hands of commuters (passengers) that move 
from one area to the other within the town. The presence of these bacteria on their hands could be an indication of lack of personal hygiene and inadequate hand washing after contact with fecal material from the environment.

Different microorganisms found in the human hands can be transferred to other parts of the body such as nose, skin, eyes, mouth, intestinal tract where they cause infections. Most of these microorganisms are capable of causing gastrointestinal diseases when accidentally ingested by the faeco-oral route (Tambekar et al., 2007).

The faeco-oral route transmission of bacteria is highly favored occurring mostly through unapparent fecal contamination of food, water and hands (Curtis et al., 2000).

Epidemiological evidence have shown that the most important risk factors are behavior's that encourage human contact with fecal matter, including improper disposal of faeces and lack of hand washing after defecation, after handling faeces and before handling food. Mostly, hand contact with ready to eat food represent a potentially important mechanism by which fecal microorganisms contaminate food and water (Yeager et al., 1999).

Many food borne diseases and pathogenic microorganisms are spread by contaminated hands (Curtis et al., 2003). Infants' exposure to feaces form greater risks of diarrhea disease by consuming contaminated water and food (WHO, 2006).

Hand hygiene has a measurable impact on reducing the burden of infection in the developing world (Aiello and Larson, 2002). Proper and good hand washing is the single most effective way to prevent the spread of communicable and infectious diseases among children and adults (Ejemot et al., 2008).
Hand washing is one of a range of hygiene promotion interventions that can interrupt the transmission of bacteria of faecal origin present on the hands of commuters and to determine the level of contamination caused by this bacteria in order to guage the importance of contaminated hands as route of transmission of bacteria of faecal origin (Curtis and Carncross, 2003). Therefore, this study was carried out to isolate faeca-bacterial pathogens associated with the hands of commuters and to possible control and hygienic measures in preventing the spread of infectious diseases.

\section{Materials and Methods}

\section{Sample collection}

Approximately 100 swab samples were collected from the hands of commuters at different motor parks (Ilesha garage, Okeijebu Park, Obaile Park, Benin Park, FUTA Park and Road-block Park) in Akure metropolis and then transported to the Microbiology laboratory for the microbiological analysis.

\section{Microbiological analysis}

The swab sticks were gently placed inside MacCartney bottle containing nine milliliter $(9.0 \mathrm{ml})$ sterile distilled water to form stock culture. For the isolation, the samples were further serially diluted to appropriate dilutions and pour plated. Enumeration of fecal-bacteria was carried out using MacConkey agar, Eosinmethylene blue agar, Deoxychocolate citrate agar and Mannitol salt agar. The agar plates were incubated at $37^{\circ} \mathrm{C}$ for 24 hours. The isolates were sub-cultured by repeated streaking on their respective media until pure cultures were obtained. The isolates were characterized based on cultural, morphological and biochemical tests, as well as sugar fermentation test (Olutiola et al., 2000). 


\section{Antibiotic sensitivity test}

The antibiotic sensitivity test of the bacterial isolates were carried out using disc diffusion in order to compare the sensitivity of the bacteria to different commercial available antibiotics according to the method described by CLSI (2009). The antibiotic sensitivity test was investigated using GBMTS discs (Abtek biological Ltd.) containing the following antibiotics: gentamycin - GN, contrimoxazole - COT, erythromycin - E, pefloxacin - PEF, ciprofloxacin - CPX, augmentin - AU, streptomycin $-\mathrm{S}$, chloramphenicol $-\mathrm{CH}$ and zinnacef $-\mathrm{Z}$, amoxicillin - AMX, ofloxacin OFL, cefriaxone - CEF, rifampin $-\mathrm{R}$, lexoflacin $-\mathrm{L}$, rifampin $-\mathrm{R}$. The commercial antibiotics were placed on nutrient agar plates previously seeded separately with 18 - 24 hours aged culture of each test microorganisms using sterile glass spreader. The plates were incubated at $37^{\circ} \mathrm{C}$ for 48 hours. After the incubation, the clear zone around each of the disc was measured as diameter zone of inhibition and interpreted accordingly. Unseeded agar plate with antibiotics served as the control. The isolates were scored either sensitive or resistant to antibiotics depending with diameter zone of inhibition.

\section{Results and Discussion}

\section{Total bacterial loads}

The total fecal-bacteria loads associated with the hands of commuters at various motor park in Akure metropolis is represented (Table 1). Highest bacterial loads $(140 \mathrm{cfu} / \mathrm{ml})$ from Obaile motor-park was recorded on Mannitol salt agar. Sample collected from Benin-park recorded high fecal-bacterial counts (106 cfu/ml) on MacConkey agar. On Eosin methylene blue agar, highest fecal-bacterial loads was obtained from Oke-Ijebu-park. On Deoxucholate agar, sample from Obaile motor pack recorded high fecal-bacterial loads (92 $\mathrm{cfu} / \mathrm{ml})$ while the least counts $(16 \mathrm{cfu} / \mathrm{ml})$ was recorded from Benin motor park. There was no significant different $(\mathrm{p}<0.05)$ in the fecalbacterial loads obtained from road block park on MacConkey, Eosin methylene blue and Deoxycholate agars. The fecal-bacteria isolated include Staphylococcus aureus, Shigella dysenteriae, Salmonella typhimorium, Escherichia coli and Klebsiella cruxii (Table 2). Staphylococcus aureus recorded high total and percentage frequency (90) from the sample locations (motor parks) followed by Esherichia coli (53) while Klebsiellacruxiihad the least value (12) (Tables 3 and 4).

\section{Antibiotic susceptibility pattern on the fecal-bacteria}

Figures 1 and 2 show the antibiotic sensitivity pattern of both Gram negative and Gram positive bacteria. All the fecal Gram negative bacterial isolates were susceptible to some of the antibiotics used with varied diameter zone of inhibition. Shigellaspp showed high sensitivity to ciprofloxacin with diameter zone of inhibition $5.0 \mathrm{~mm}$. Escherichia coli was resistant to pefloxacin and lexoflacin (Figure 1). Staphylococcus aureus showed resistant to erythromycin, pefloxacin, zinnacef, amoxicillin and lexoflacin with high sensitivity to gentamycin - GN, contrimoxazole - COT, ciprofloxacin - CPX, augmentin - AU, streptomycin - S, chloramphenicol - $\mathrm{CH}$, ofloxacin - OFL, cefriaxone $-\mathrm{CEF}$ and rifampin $-\mathrm{R}$ (Figure 2).

Human hygiene play significant roles in the bacterial contamination. Commuters in the same vehicle can transmit faecal organisms to one another and to other commuters entering the same vehicle through touch contamination. The percentage of bacteria isolated from the hands of the commuters at different motor packs varied with respect to the level of contamination (Lynn et al., 2013). Different 
microorganisms have been found to associate with the hands of humans selling along the road sides and commercial places. The presence of these microorganisms indicates the level of unhygiene by the commuters which could pose threat to human health. The increase in total bacterial counts from Obaile Motor Park may be due poor hygienic conditions of the commuters or direct contact with fecal contaminating surfaces and materials. The prevalence of microbiota in the various motor parks could be attributed to the poor hygienic associated with the low level of education of the commuters attending the parks at the time of the study. The spread of infectious disease by the commuters could be attributed to the improper hand washing after defecating, touch of contaminated surfaces such as seats, stirring, walls, tires, luggage and soils (Chinakwe et al., 2012). Human habit such as washing hands with contaminated or dirty water might be a source of fecal-bacteria and other pathogenic microorganisms (Rather, 2009). Isolation of Staphylococcus aureus from the human skin has been reported (Willey et al., 2008). Ray et al., (2011) had reported isolation of $S$. aureus, E. coli, Enterococcus faecalis, Klebsiella spp from the hands of the students. Similarly, Chinakwe et al., (2012) had reported the presence of $E$. coli, Pseudomonas spp, Proteus spp, Citrobacter spp, Klebsiella spp, Salmonella spp, Enterobacter spp. and S. aureus from the hand wash and swabs of students. The percentage contamination of Staphylococcus aureus on the hands of commuters at the motor parks was found to be high, above $80 \%$ compared to other bacteria. The presence of Staphylococcus aureus could be a normal flora of the skin and not necessarily an indicator of fecal contamination. High occurrence of Escherichia coli, Shigella and Salmonella from Okeijebu, Obaile and Benin motor parks might be due to poor hygienic condition, inadequate hand washing, lack of access to water, high population of illiteracy and uneducated people in the motor parks. The prevalence and highest percentage of bacterial contamination causing diarrhea among poor people and middle economic status has been reported (Itah and Ben, 2004; Tambekar et al., 2009). The low bacterial counts recorded among the commuters from FUTA car park might be attributed to the good hygiene practices among the students and the drivers. The reduction in the number of pathogens after hand washing was also reported by Tambekar et al., (2009). Hygiene promotion may be cost effective intervention of preventing infectious diseases in developing countries (Curtis et al., 2003). Isolation of transmissible microorganisms through handshake has been reported (Oniya et al., 2006). The results obtained were similar to the findings of Mohsen (2017) who reported isolation of some enteric microorganisms from under the fingernails.

Table.1 Total fecal-bacterial loads

\begin{tabular}{|c|c|c|c|c|}
\hline Sample location & \multicolumn{4}{|c|}{ Fecal-bacterial loads (cfu/ml) } \\
\hline & $\mathrm{McA}$ & EMB & DCA & MSA \\
\hline Obaile motor park & 80 & 68 & 92 & 140 \\
\hline F.U.T.A Cab park & 20 & 66 & 18 & 11 \\
\hline Benin motor park & 106 & 40 & 16 & 17 \\
\hline Oke-Ijebu motor park & 48 & 88 & 58 & 18 \\
\hline Road-block motor park & 54 & 50 & 52 & 92 \\
\hline
\end{tabular}

Key: McA - MacConkey agar, EMB - Eosin-methylene blue agar, DCA - Deoxychocolate citrate agar, MSA Mannitol salt agar. 
Table.2 Morphological and biochemical characteristics of the fecal-bacteria isolated from the hands of the commuters in Akure metropolis

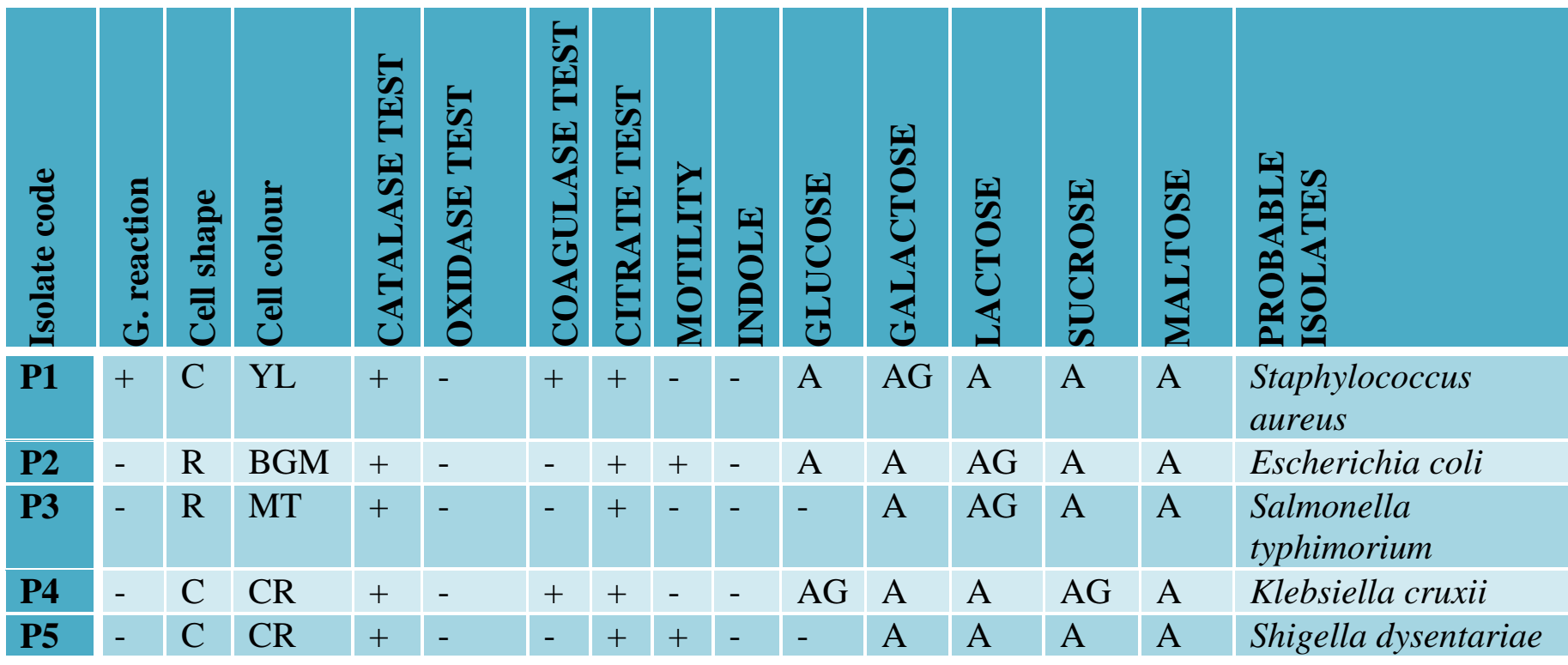

Key: $+=$ Positive/absent, $-=$ negative/present, $\mathrm{C}=$ cocci, $\mathrm{R}=\operatorname{rod}, \mathrm{YL}=$ yellowish, $\mathrm{MGM}=$ brilliant green metallic, $\mathrm{MT}=$ metallic green, $\mathrm{A}=$ acid production, $\mathrm{AG}=$ acid and gas production

Table.3 Determination of frequency of fecal-bacteria

\begin{tabular}{|l|l|l|l|l|l|l|}
\hline Sample location & $\begin{array}{l}\text { Sampl } \\
\text { e size }\end{array}$ & $\begin{array}{l}\text { Escherichia } \\
\text { coli }\end{array}$ & $\begin{array}{l}\text { Staphylococcus } \\
\text { aureus }\end{array}$ & $\begin{array}{l}\text { Salmonella } \\
\text { typhimorium }\end{array}$ & $\begin{array}{l}\text { Shigella } \\
\text { dysenteriac }\end{array}$ & $\begin{array}{l}\text { Klebsiella } \\
\text { cruxii }\end{array}$ \\
\hline Obaile park & 20 & 14 & 17 & 8 & 7 & 4 \\
\hline Benin park & 20 & 13 & 20 & 4 & 1 & 1 \\
\hline Road block & 20 & 7 & 17 & 2 & 1 & 2 \\
\hline F.U.T.A park & 20 & 10 & 16 & 1 & 1 & 3 \\
\hline Oke-jjebu park & 20 & 9 & 20 & 5 & 4 & 2 \\
\hline Total & 100 & 53 & 90 & 20 & 14 & 12
\end{tabular}

Table.4 Percentage frequency of the fecal-bacteria

\begin{tabular}{|l|l|l|l|l|l|l|}
\hline $\begin{array}{l}\text { Sample } \\
\text { location }\end{array}$ & $\begin{array}{l}\text { Sample } \\
\text { size }\end{array}$ & E. coli & $\begin{array}{l}\text { Staph. } \\
\text { aureus }\end{array}$ & Salmonellaspp & Shigellaspp & Klebsiellaspp \\
\hline Obaile park & 20 & $14(70 \%)$ & $17(85 \%)$ & $8(40 \%)$ & $7(35 \%)$ & $4(20 \%)$ \\
\hline $\begin{array}{l}\text { Benin block } \\
\text { Road } 20\end{array}$ & 20 & $13(65 \%)$ & $20(100 \%)$ & $4(20 \%)$ & $1(5 \%)$ & $1(5 \%)$ \\
\hline park & $7(35 \%)$ & $17(85 \%)$ & $2(10 \%)$ & $1(5 \%)$ & $2(10 \%)$ \\
\hline $\begin{array}{l}\text { F.U.T.A Cab } \\
\text { park }\end{array}$ & 20 & $10(50 \%)$ & $16(80 \%)$ & $1(5 \%)$ & $1(5 \%)$ & $3(15 \%)$ \\
\hline $\begin{array}{l}\text { Oke-ijebu park } \\
\text { Total }\end{array}$ & 100 & $53(53 \%)$ & $90(90 \%)$ & $20(20 \%)$ & $14(14 \%)$ & $12(12 \%)$ \\
\hline
\end{tabular}


Fig.1 Antibiotic sensitivity pattern of Gram negative bacteria

6

Esherichia coli

5

4

CN COT E

Salmonella typhi

Shigella spp

Klebsiella spp

Key: gentamycin - GN, contrimoxazole - COT, erythromycin - E, pefloxacin - PEF, ciprofloxacin - CPX, augmentin - AU, streptomycin $-\mathrm{S}$, chloramphenicol $-\mathrm{CH}$, zinnacef $-\mathrm{Z}$, amoxicillin - AMX, ofloxacin - OFL, cefriaxone - CEF, rifampin $-\mathrm{R}$ and lexoflacin $-\mathrm{L}$.

Fig.2 Antibiotic sensitivity pattern of Gram positive bacteria

14

12

10

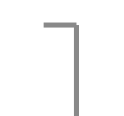

Staphylococcus aureus

8

6

4

2

0

CN COT E PEF CPX AU $S \quad C H \quad Z$ AMX OFL CEF $R \quad L$

Key: gentamycin - GN, contrimoxazole - COT, erythromycin - E, pefloxacin - PEF, ciprofloxacin - CPX, augmentin - AU, streptomycin - S, chloramphenicol - $\mathrm{CH}$, zinnacef $-\mathrm{Z}$, amoxicillin - AMX, ofloxacin - OFL, cefriaxone - CEF, rifampin $-\mathrm{R}$ and lexoflacin $-\mathrm{L}$. 
Lack of uniform information on the use of antibiotics may have led to the emergence of resistant bacterial strains. The presence of multidrug resistant pathogens in the hand of commuters at various motor parks in Akure presents a major threat to human life. Though little information are available on the resistant of microorganisms isolated from the hands of commuters in Akure metropolis.

Nevertheless, adequate policy on the use of antibiotics could effectively address the curative measure in the control and prevention of infectious diseases associated with humans (Klutmans et al., 1997). The presence of multiple drug resistant pathogens from the hands of the commuters at various park present a major threat to human life since different group of commuters come in contact with each either going on transit or for commercial purpose at the various parks. The emergence of resistant bacteria to some antibiotics might be attributed to the genetic manipulation and environmental stress. Staphylococcus spp is known as medically important pathogens of great health concern (Martin et al., 2017). The resistance of Staphylococcus aureus to erythromycin, pefloxacin, zinnacef and amoxicillin might be due to the presence of peptidoglycans in the cell wall and certain enzymes among other virulence factors (Daka et al., 2012). Aiello et al., (2003) reported occurrence of antibioticresistant microorganisms from the hands of individuals. The resistance of Gram negative strains to most antibiotics more than Gram positive due to the intrinsic nature of their cell wall has been reported (Agersew et al., 2015). The result obtained from this study was in agreement with the findings of Ogundare and Ekundayo (2016) who reported the resistant of $S$. aureus to pefloxacin.

In conclusion, this study revealed the microbial loads on the hygiene level among the commuters at various motor parks in
Akure metropolis. Regular surface washing of hands with disinfectant can contribute to the reduction of human hands contamination and the transmission of pathogenic microorganisms among the commuters. The types of microorganisms isolated could induce the attention of epidemiologists and health policy makers to the emergence of the antibiotic resistant bacteria. Proactive measures through compliance to hand washing practices and disinfection of personal items can be taken in the prevention of an outbreak of infectious diseases that could be difficult to handle. More also, periodic bacteriological monitoring, appropriate antimicrobial resistance surveillance and prevention approach should be adopted in curtailing the spread of fecal-contamination among the commuters. Therefore, multiple drug resistant Staphylococcus aureus isolated from the hands of the commuters should be critically address by the government by ensuring hand washing strategy at various parks in Akure metropolis and adequate health services in order to ensure safety and healthy living of the commuters.

\section{References}

Agersew A., Degisew M. and Yitayih W. (2015). Bacterial profile and their antimicrobial susceptibility patterns of computer keyboards and mice at Gondar University Hospital, Northwest Ethiopia. Biomed Biotechnol, 3(1): 1-7.

Ahmad N. S., Nosheen W. Y., ShaguftaS. H., Imran A.S.A. and Sadaf I. (2014). Antibacterial activity of liquid hand washes against daily encounter bacteria. IOSR J Pharm, 4(2): 19-23.

Aiello A. E. and Larson E. L. (2002). What is the evidence for a casual link between hygiene and nfections? Lancet Infectious Disease, 2: 103 - 110.

Barker J. and Bloomfield S. F. (2000). Survival of Salmonella in bathrooms 
and toilets in domestic homes following Salmonellosis. J. Applied Microbiol, 89(1): 137-144.

Chinakwe E. C., Nwogwugwu N. U., Nwachukwu I. N., Okorondu S. I., Onyemekara N. N. and Ndubuisi-Nnaji U. U. (2012). Microbial quality and public health implications of hand-wash water samples of public adults in Owerri, South-East Nigeria. Int. Res. J. Microbiol, 3(4): 144-146.

Clinical and Laboratory Standards Institute (2009). Performance standards for antimicrobial susceptibility testing. Nineteenth informational supplement. Page 100-119.

Curtis V, Biran A, Deverell K, Judges C, Bellamy K. and Drasar B. (2003). Hygiene in the Home: Relating bugs and behavior. Soc. Sci. Med, 57: 657672.

Curtis V. and Cairncross S. (2003). Effect of washing hands with soap on diarrhea risk in the community: A systemic review. Lancet Infectious Diseases, 3: 275-281.

Daka D, Solomon G. and Yihdego D. (2012). Antibiotic resistance Staphylococcus aureus isolated from cow's milk in the Hawassa area, South Ethiopia. Ann Clin Microbiol Antimicrob, 11: 26-37.

Dodrill L., Schmidt W.P., Cobb E., Donachie P., Curtis V. and De-Barra M. (2011). The effect of hand washing with water or soap on bacterial contamination of hands. Int. J. Environ. Public Health Res, 8(1): 97- 104.

Ejemot R. I., Ehiri J. E., Meremikwu M. M. and Critchley J. A. (2008). Handwashing for preventing diarrheoa. Cochrane Database System, 23(1): 7-9.

Itah A. Y. and Ben A. E. (2004). Incidence of enteric bacteria and Staphylococcus aureus in Daycare Centers in Akwa Ibom State Nigeria. The Southeast
Asian J. Tropical Med. Public Health, 35(1): 202-209.

Johnson S. A., Goddard P. A., Iliffe C., Timmins B., Rickard A. H., Robson G. and Handley P. S. (2002). Comparative susceptibility of resident and transient hand bacteria to para-chloro-metaxylenol and triclosan. $J . A p p l$. Microbiol, 93: 336-344.

Klutmans J, Van Belkum A. and Verbrugh H. (1997). Nasal carriage of Staphylococcusaureus: Epidemiology, underlying mechanisms and associated risks.Clin. Microbiol. Rev, 1(3): 505 520.

Lau C. H., Springston E. E., Sohn M., Mason I., Gadola E., Damitz M., Lin C., Wu F. M., Doyle M. P., Michaels B. S. and Williams K. (2002). Removal of Escherichia coli on hands with naturalmor artificial fingernails. International J. Epidemiol, 21: 11571164.

Lynn M, Vivian O. A. andWasa A. A. (2013). The prevalence of bacterial organisms on toilet door handles in Secondary Schools in Bokkos L. G. A., Jos, Plateau Sate, Nigeria. IOSR J. Pharm Biolog. Sci, 8(4): 85-91.

Martin E, Bhattacharya S., Christiansen B., Gebel J. andSchülke R. (2017) Antibiotic resistance: What is so special about multidrug-resistant Gramnegative bacteria? GMS Hyg Infect Control, 12: Doc05

Mohsen H. R (2017). Isolation and identification of bacteria from under fingernails. Int. J. Curr. Microbiol Applied Sci, 6(8): 3584-3590.

Ogundare A. O. and Ekundayo F. O. (2016). Antibiotic sensitivity profile of Staphylococcus species from anatomical and environmental sites in the Federal University of Technology, Akure, Nigeria. British Biotechnol. J, 10(1): 18. 
Olutiola P. O., Famurewa O. and Sonntag H. G. (2000). Introduction to microbiology. Practice approach. Second Edition, Publing and Media Consults, Nigeria. pp. 25-50.

Oniya M. O., Obajuluwa S. E., Alade E. T. and Oyewole O. A. (2006). Evaluation of microorganisms transmissible through handshake. Afr. J Biotechnol, 5(11): 118-112.

Oranusi S., Dahunsi S.O., Owoso O. O. and Olatile T. (2013). Microbial profiles of hands, foods, easy contact surfaces and food contact surfaces: A case study of a University Campus. Novus Int. J. Biotechnol. Biosci, 2(1): 30-38.

Patel H. R., Daniel P. S. and Patel C. N. (2010). Role of community pharmacist in assessing the awareness of hand hygiene in rural area. J. Global Pharma Technol, 2(5): 59-61.

Prescott L. M., Harley J. P., and Klein D. A. (2005). Microbiology. 6th ed. Tim McGrawHill

Ray S. K., Amarchand R., Srikanth J. and Majumdar K. K. (2011). A study on prevalence of bacteria in the hands of children and their perception on hand washing in two schools of Bangalore and Kolkata. Indian J. Public Health, 55(4): 293-297.

Rote R. B., Deogade N. G. andKawale M. (2010). Isolation, characterization and antibiotic sensitivity of organism from Indian currency. Asiatic J Biotechnol. Res, 3: 255-60.

Tambekar D. H., Shirat S. D. and Suradkar S. B. (2007). Prevention of transmission of infectious diseases: Studies on hand hygiene in health-care among student. Continental J. Biomedical. Sci, 1: 6-10.

Tambekar D. H., Shirsat S. D., Kakde S. R. and Ambekar K. B. (2009). Hand hygiene and health: An epidemiological study of students in Amravati. African J. Infectious Disease, 3(1): 26-30

WHO Guidelines on Hand Hygiene in Health Care: First Global Patient Safety Challenge Clean Care Is Safer Care. Geneva: World Health Organization; 2009. 5, Normal bacterial flora on hands. Available from: https://www. ncbi.nlm.nih.gov/books/NBK144001/

\section{How to cite this article:}

Ologun Oluwabusayo Mary. 2018. Isolation, Enumeration and Antibiotic Sensitivity Pattern of Bacteria from the Hands of Commuters in Akure Metropolis. Int.J.Curr.Microbiol.App.Sci. 7(11): 3423-3432. doi: https://doi.org/10.20546/ijcmas.2018.711.393 